\title{
Laboratoriumzinnen in het tijdperk van de kwantitatieve taalkunde
}

\author{
Sjef Barbiers \\ NT 25 (2-3): 177-179 \\ DOI: 10.5117/NEDTAA2020.2-3.002.BARB
}

\begin{abstract}
Laboratory sentences in the era of quantitative linguistics

This paper briefly compares an early (1996) and a later (2010) article that I published in Nederlandse Taalkunde, concentrating on the different methodologies underlying the two papers: A formal theoretical in-depth analysis of one idiolect in the first paper and a large-scale quantitative and theoretical approach in the second. It is argued that the two methods make different contributions and are both necessary to develop a theory of (im-)possible syntactic structures in natural language.
\end{abstract}

Keywords: grammaticality judgments, theoretical linguistics, quantitative linguistics, experimental linguistics

Mijn onderzoeksprogramma laat zich samenvatten in een vraag van zes woorden: Wat is een (on-)mogelijke natuurlijke taal? Het antwoord op die vraag moet een model opleveren van de kennis die een spreker heeft van zijn of haar moedertaal, de mentale grammatica. Hoe die kennis wordt verworven en gebruikt wordt getoetst in andere disciplines, zoals taalontwikkelingsonderzoek, psycho- en neurolinguïstiek, pragmatiek, sociolinguïstiek en AI.

Mijn artikelen over de syntaxis van het Nederlands in het tijdschrift Nederlandse Taalkunde zijn allemaal bedoeld als bijdrage aan de beantwoording van die ene vraag. Ze maken alle gebruik van de generatieve methode. Het zijn theoriegestuurde, formele analyses van de idiolecten van moedertaalsprekers, waarin opzettelijk geabstraheerd wordt van allerlei 
factoren die, naar ik aanneem, niet tot de mentale grammatica behoren. Taal is zo'n immens complex systeem dat we niet alles tegelijk kunnen onderzoeken. Zoals in elke wetenschap is reductie en idealisering van het onderzoeksobject noodzakelijk.

Ik onderzoek niet alleen in het wild voorkomende taaluitingen. Die geven wel inzicht in wat voorkomt, maar niet in wat zou kunnen voorkomen, en ook niet in wat niet voorkomt. Ze geven ook geen inzicht in hoe taal in elkaar zit, zoals de relatie tussen hiërarchische structuur en semantische interpretatie. De gegevens voor mijn artikelen werden daarom verzameld met behulp van grammaticaliteitsoordelen over in het laboratorium gefabriceerde testzinnen. Experimentele taalkunde dus. In het eerste artikel uit 1996, over modale werkwoorden, waren dat vooral mijn eigen oordelen. In het artikel uit 2010 met Olaf Koeneman en Marika Lekakou, over lange vraagwoordafhankelijkheden, kwamen de oordelen van meer dan 5 oo dialectsprekers verspreid over 267 plaatsen in het gehele Nederlandse taalgebied.

De betrouwbaarheid en bruikbaarheid van grammaticaliteitsoordelen bij de studie van idiolecten zou niet meer ter discussie mogen staan na het werk van onderzoekers als Ion Sprouse, Diogo Almeida en Carson Schutze. Dat werk laat zien dat zulke oordelen robuust en stabiel zijn (zie Schutze \& Sprouse 2013 en Sprouse \& Schutze 2020 voor overzichten). De replicatiestudie van Sprouse \& Almeida (2012) toont ook aan dat de informele grammaticaliteitsoordelen waarop een groot deel van de theoretische literatuur is gebaseerd 95 tot 98 procent overeenstemming vertonen met de grammaticaliteitsoordelen verkregen met experimenteel onderzoek dat gebruik maakt van de best practices uit de sociale wetenschappen. Sprouse en Schutze geven tal van suggesties over hoe grammaticaliteits-oordelen het beste kunnen worden verzameld, maar het is duidelijk dat niet alle syntactici zich hoeven om te scholen tot sociale wetenschappers.

Is dat artikel uit 2010 nu meer waard dan dat artikel uit 1996, omdat het gebaseerd is op veel meer oordelen over veel meer constructies van veel meer sprekers in veel meer variëteiten van het Nederlands, en daardoor statistische analyse mogelijk maakt? Ik zou zeggen van niet. Het artikel uit 1996 is een diepgravende studie van de syntaxis van modalen in één idiolect. Het beschrijft hoe Nederlandse zinnen met modale werkwoorden in elkaar zitten en welke relatie er is tussen die bouw en vier subtiel verschillende typen modale betekenissen. Op basis daarvan kunnen hypothesen worden geformuleerd over hoe modale constructies in andere talen in elkaar zitten. 
Vergeleken daarbij is het artikel uit 2010 een 'oppervlakkige' studie. Dat artikel levert echter weer wel observaties en generalisaties op die met de studie van één idiolect niet hadden kunnen worden ontdekt, zoals het bestaan van vier verschillende vraagwoordverdubbelings-constructies en de generalisatie dat het eerste vraagwoord in een zin met verdubbeling niet meer gespecificeerd kan zijn dan het tweede vraagwoord, een bijdrage aan de notie (on-)mogelijke taal. Zulk grootschalig onderzoek kan ook correlaties tussen taalverschijnselen opleveren die relevant zijn voor ons inzicht in het taalsysteem (zie Barbiers et al. 2016 en Barbiers et al. 2018).

Het is een saaie conclusie, maar wel waar. Zowel diepgaand onderzoek naar één constructie in één idiolect als grootschalig onderzoek naar grote hoeveelheden constructies in een groot aantal idiolecten is nodig om te ontdekken hoe de syntaxis van natuurlijke taal in elkaar zit. In de ideale wereld zouden beide benaderingen met elkaar gecombineerd worden. Maar in de praktijk zijn beide methoden zo tijdrovend, arbeidsintensief, veeleisend en complex dat het vaak onmogelijk is om ze te combineren. Daarom kies ik de ene keer de ene en de andere keer de andere methode, mede afhankelijk van de specifieke onderzoeksvraag.

\section{Referenties}

Barbiers, Sjef (1996). Complementen van modale werkwoorden. Nederlandse Taalkunde 1(2), 135-154.

Barbiers, Sjef, Olaf Koeneman \& Marika Lekakou (2010). Vragen aan de linkerperiferie. Nederlandse Taalkunde 15(3), 284-307.

Barbiers, Sjef, Hans Bennis, Majo van Koppen \& Norbert Corver (2016). Microcomparative Morphosyntactic REsearch (MIMORE): Mapping partial grammars of Flemish, Brabantish and Dutch. Lingua 178, 5-31.

Barbiers, Sjef, Hans Bennis \& Lotte Dros-Hendriks (2018). Merging verb cluster variation. Linguistic Variation 18(1), 144-196.

Schütze, Carson \& Jon Sprouse (2013). Judgment data. In: Robert J. Podesva \& Devyani Sharma (red.), Research Methods in Linguistics. New York: Cambridge University Press, 27-50.

Sprouse, Jon \& Diogo Almeida (2012). Assessing the reliability of textbook data in syntax: Adger's Core Syntax. Journal of Linguistics 48, 6o9-652.

Sprouse Jon \& Carson Schutze (2020). Grammar and the use of data. In: B. Aarts \& G. Popova (red.), The Oxford Handbook of English Grammar. Oxford: Oxford University Press.

\section{Over de auteur}

Sjef Barbiers, Universiteit Leiden

E-mail: sjef.barbiers@hum.leidenuniv.nl 
